\title{
Tonsillar Pillar
}

National Cancer Institute

\section{Source}

National Cancer Institute. Tonsillar Pillar. NCI Thesaurus. Code C12236.

The anterior and posterior borders of the tonsillar fossa. They are composed of muscle tissue. 